\title{
Is There Rule of Law in Russia: Revisiting the Concept and Practice
}

\section{Introduction}

\author{
Marianna Muravyeva \\ Aleksanteri Institute, Finnish Centre for Russian and East European \\ Studies, Faculty of Law, University of Helsinki, Finland \\ marianna.muravyeva@helsinki.fi
}

Globalization challenges many of the traditional assumptions about domestic law, international law, their relationships, the ways in which law is created and the methods of its enforcement. ${ }^{1}$ Law has traditionally been the province of the nation state, whose courts and police enforce legal rules. By contrast, international law has been comparatively weak, with little effective enforcement powers. But globalization is changing the contours of law and creating new global legal institutions and norms. It also brings universal concepts such as rule of law and good governance to national systems and local legal environments. ${ }^{2}$ As 'rule of law' has become part of the global lexicon, its precise meaning has become increasingly opaque. ${ }^{3}$ There is an agreement with the principle that law should apply in equal measure to everyone, irrespective of wealth or political status; 'equal justice under law' is generally accepted as the foundational principle of the rule of law. Coupled with good governance principles, the application of these concepts to the Russian legal context reveals complex issues that need to be discussed beyond the Russian domestic sphere. Such discussion is even more important in situations leading to global law or universal law concepts, which require a diverse set of legal systems that

1 William E. Scheuerman, "Economic Globalization and the Rule of Law 1", in Richard Bellamy (ed.), Constitutionalism and Democracy (Routledge, New York, 2017).

2 Heike Krieger and Georg Nolte, "The International Rule of Law - Rise or Decline? Approaching Current Foundational Challenges", in Heike Krieger, Georg Nolte, and Andreas Zimmermann (eds.), The International Rule of Law: Rise or Decline? (Oxford University Press, Oxford, 2019).

3 Richard Bellamy, "The Rule of Law”, in Richard Bellamy and Andrew Mason (eds.), Political Concepts (Manchester University Press, Manchester, 2018). 
are often seen as incompatible, to make an effort to find areas of convergence rather than divergence. ${ }^{4}$

In this context, Russian law faces challenges both domestically and internationally, as it comes to terms with the standards of globalization and adjusts to the dramatic inter-influences of various legal systems, institutions, and laws. There is a need to discuss the place of Russian law in globalization processes, the theoretical and practical problems it faces from inside and outside, and how to proceed in situations of legal tensions and conflict resolution. More than that, this discussion cannot be only focused on Russian law as thing-initself, but requires comparative approaches and dialogue between legal scholars and practitioners in Russia and beyond about common legal concerns and issues. The articles in this issue explore a variety of ways in which Russian law deals with the above-mentioned challenges.

Russia has been struggling with the rule-of-law concept since it announced its commitment to develop it in the 1990s. ${ }^{5}$ Emerging from its Soviet past, Russia plunged into democratic reforms, committed to building a market economy, and hastened to transform its law to adapt to the new political and economic realities. In 1996, Russia became a member of the Council of Europe without fully developed rule of law but with hope that Russia's participation in the $\mathrm{CoE}$ and, especially, in the European Court of Human Rights, would eventually bring rule of law. Twenty-five years later, Jeffrey Kahn analyzes the consequences and results of Russia's membership in the CoE in his essay here. Kahn stresses the instrumental use of law that leads to the dual legal State that deals differently with ordinary and what is labelled 'political' cases, that is, those in which the State asserts its special prerogative to intervene as it chooses. ${ }^{6}$ In his opinion, the original politically motivated decision to accept the Russian Federation, newly emerged from the Soviet rule, to the CoE has had more negative than positive consequences in the long run, considering recent attempts to re-negotiate relations between Russia and the ECtHR as to the latter's jurisdiction. Kahn insists that there is a lack of ruleof-law legal culture in officials and institutions that prevents Russia's development of the rule of law on its own. Kahn's approach to the rule of law as a

4 Giuliana Ziccardi Capaldo, The Pillars of Global Law (Routledge, London, 2016).

5 Jeffrey Kahn, "The Search for the Rule of Law in Russia", 37 Georgetown Journal of International Law (2005), 353-410.

6 On the dual state see Richard Sakwa, "The dual state in Russia", 26(3) Post-Soviet Affairs 26 (2010), 185-206; on legal dualism see Kathryn Hendley, "Varieties of legal dualism: making sense of the role of law in contemporary Russia", 29 Wisconsin International Law Journal (2011), 233-262. 
structural and embedded component of governance leads him to pessimistic and highly critical assessments of the likelihood of Russian officials ever allowing further constraints on their power, and even to perceive attempts to rollback important, existing limits imposed by Strasbourg.

On the contrary, Sergey Marochkin in his article offers a more pragmatic view of Russia's uses of the rule of law in the comparative international context. He analyses the collision between law on the books and 'live law' to show that, in international relations, the states in fact do not follow law on the books but rather 'live' law that emerges in a specific practical situation. In his opinion, the rule of law often fails in its ultimate role - as a mediator, an 'equalizer' and 'limiter' for the parties - and is not actually used in basic matters of interstate relations. There is a clear distinction between proclaimed adherence to this principle and the actual behavior of states: often their actions continue to be predetermined by the age-old habit of 'might makes right'. States demonstrate their inability to limit themselves by law. Pressing world problems and disasters should not be seen as an 'agony' and 'crisis' of international law - as state officials often say - but as a result of states' backward thinking, their desire for domination and superiority rather than restraint, tolerance, and equal opportunities provided by law. Russia fits very well among this ageing system of international law that requires fundamental revision.

Kahn's and Marochkin's analyses highlight the discrepancy between an idealistic philosophical concept of the rule of law and an assessment of whether rule of law, in fact, exists or even should exist in a particular locality. Current scholarship is very critical of narrow idealistic definitions of the rule of law that emerged from the national context of the 'core West' insisting that the major goal of the concept is to constrain arbitrary rule. ${ }^{7}$ Martin Krygier notes that arbitrariness is notoriously undertheorized, however, there are at least three different examples of it. One form is found where power-wielders are not subject to routine, regular control or limit, or accountability to anything other than their own will or pleasure. In a second sense, power is exercised arbitrarily when those it affects cannot know, predict, understand, or comply with the ways power comes to be wielded. That is the form typically responded to in the various 'laundry lists' of formal characteristics of legality or the rule of law. A third way in which power can seem arbitrary is when the exercise of power, even if tempered and/or predictable, allows no space or makes no means available for its targets to be heard, to question, to inform, or to affect

7 Bellamy, op.cit. note 3; Martin Krygier and Adam Winchester, "Arbitrary Power and the Ideal of the Rule of Law", in Christopher May and Adam Winchester (eds.), Handbook on the Rule of Law (Edward Elgar Publishing, Cheltenham, 2018). 
the exercise of power over them and no requirement that their voices and interests be considered in the exercise of that power. ${ }^{8}$

Russia has exhibited all three, which requires a much more complex approach to how rule of law could be established, or if any other version of the rule-of-law concept, such as Rechsstaat, would be more culturally compatible with the region. ${ }^{9}$ Some scholars perceive rule of law as one of the 'losers' of globalization. ${ }^{10}$ The economic crisis of 2008 had a fundamental impact on the rule of law as the recession and austerity policies afterwards aggressively mandated transnational institutions to act over the nation states that created them in the first place. A well-known example is the set of novel legal mechanisms for dealing with the sovereign debt crisis in Europe. Z. Umut Türem highlights how globalization chips away at the fundamental characteristics of the rule of law as it introduces executive discretion/arbitrariness and elements of authoritarian implementation in the formation of these economic emergency policies. ${ }^{11}$ Here rule of law emerges as a juxtaposition of thin and thick concepts of the rule of law: thin, if you are committed to a formal, institution-focused concept, or thick, if one prefers a substantive or material concept of it. ${ }^{12}$

Russia has been sticking to the 'thin' variety in its economic integration by implementing and transplanting institutions that would exhibit the presence of the rule of law. Despite Russia's open criticism of international institutions, including judicial organizations such as the ECtHR, it still follows guidelines and adapts to institutional design of international bodies it chooses to accept. Grigory Vaypan's assessment of the Dubovets vs Russia ECtHR case in this issue shows that Russia's inclusion in European and international institutions has had a profound impact on the Russian legal system and governance, no matter what politicians declare. Russia's response to the ECtHR's Dubovets ruling exhibits willingness to amend civil law and remedy the situation in one of the

8 Ibid., 76-77; Jeremy Waldron, "The rule of law and the importance of procedure", 5o Nomos (2011), 3-31.

9 On rule of law and Rechsstaat see: Martin Krygier, "Rule of law (and Rechtsstaat)", in James R. Silkenat, James E. Hickey Jr., and Peter D. Barenboim (eds.), The Legal Doctrines of the Rule of Law and the Legal State (Rechtsstaat) (Springer, Cham, 2014).

10 Peer C. Zumbansen, "The Rule of Law, Legal Pluralism, and Challenges to a Westerncentric View: Some Very Preliminary Observations", in Christopher May and Adam Winchester (eds.), Handbook on the Rule of Law (Edward Elgar Publishing, Cheltenham, 2018). Z. Umut Türem, "Rising Authoritarianism(s) and the Globalization of Law: An Initial Exploration", 26(1) Indiana Journal of Global Legal Studies (2019), 1-30.

12 Rachel Kleinfeld, "Competing definitions of the rule of law", in Thomas Carothers (ed.), Promoting the rule of law abroad: in search of knowledge (Carnegie Endowment for International Peace, Washington, D.C., 2006). 
crucial areas of private law-property claims. The case also shows the very will to impose the restraint on State claims for state property thus breaking a tradition of prioritizing state's interests. Vaypan rightfully calls it 'a landmark case' because it takes private property's protection on a new level and at the same time imposes the type of restraint on the state agencies that Jeffrey Kahn argues is sometimes lacking in Russia. This willingness to comply indicates the presence of 'thin' institution focused will to reform.

As with many other governments, too, particularly authoritarian ones, Russia prefers to be assessed against thin formal criteria which are easier to satisfy than thick, morally demanding perspectives. Today some international business people, unwilling to wade into controversial questions about democracy or human rights may often prefer a formal, thin, conception too. Thomas Kruessmann looks at the compliance movement in the Russian corporate sector. He seeks to open up a new perspective on the rule-of-law dialogue between the West and Russia. He questions whether, in the light of the style of Russian law, adopting Western models of risk management and corporate compliance may lead to a rule-of-law culture in Russian corporations. The answer to this question, in his opinion, is not entirely clear-cut. After twenty years of legal developments that followed an essentially dialectic pattern, one sees a strong path dependence in giving boards of directors ultimate responsibility for the risk management and compliance systems to be established. Kruessmann is positive that Russian corporations might be the ones developing rule-of-law culture outside the traditional domain of citizen-state relations.

The flipside of following the thin concept of the rule of law is that the substantive meaning of it is lost in translation. While Russia exhibits high levels of institutional design that superficially resembles those required for the rule-of-law especially in a market economy framework, the social and cultural notions remain unchanged and undermine institutional compliance. Russian lawmakers and politicians continue instrumental and political uses of law, often to serve the interests of a very abstract 'State' that results in tightening control over public and private spheres of life. These processes are evident in dealing with civil rights and an independent judiciary, two fundamental aspects of the rule-of-law concept.

Elena Sherstoboeva explores the poor extent to which Russian regulation of traditional TV and online audiovisual media policies has been consistent with CoE standards while entering the digital age. In this sphere, thin institutionbased understandings of the rule-of-law clash with deeplyingrained ideology of authoritarian state to control information flow in every detail. Sherstoboeva shows that CoE standards have had an almost superficial impact on Russian audiovisual regulation. Even more, non-compliance has increased since 2014, 
which might be connected with Russia's annexation of Crimea and subsequent sanctions affecting the Russian economy and Russian politics. While European supranational audiovisual regulation is becoming extremely multidimensional, the Russian legal audiovisual framework seems to have largely developed as a governmental tool for direct or indirect control over the audiovisual media sector. In exchange for financial or other privileges, the Russian audiovisual media industry has to accept the paternalistic mode of regulation and assume its role of governmental mouthpiece in harsh market conditions. Russia follows its usual 'thin' rule of law adherence strategy by imitating $\mathrm{CoE}$ institutions or concepts, such as 'private media ownership', 'public service media', 'online audiovisual services', or 'media regulator' while effectively shutting down the freedom of expression.

The desire to 'imitate' international structures led Russia to initiate interregional integration by creating in 2015 the Eurasian Economic Court (EAEU), an international organization for regional economic integration in the post-Soviet space that has a judicial body aimed at ensuring uniform application of law. This new supranational judicial body was supposed to become an alternative region oriented system of law enforcement confirming that rule of law could emerge in non-Western or non-European context. Maksim Karliuk examines how the EAEU promotes rule of law and if it is successful in maintaining its judicial independence and the routine application of due process of law. However, from its very founding the Court began to lose some of its independence and experienced limitations on its powers, especially on its interpretive practices. This made it considerably more difficult to achieve its objective of ensuring uniform application of EAEU law. Perhaps because of the Court's relatively weakly functioning power to issue advisory opinions, member states have reinforced their role as the ultimate shapers of the Eurasian legal landscape rather than the judges of the court. The Court started to show clear signs of caution, trying to make the political impact of its judgments minimal, especially in politically charged state vs. state litigation, showing traits of 'legal diplomacy'. It is ironic how the EAEU story reflects the pathways in which judicial power could be appropriated internationally.

I hope that this current issue of the Review of Central and East European Law reopens the dimmed debate on how rule of law as both a concept and as practice can be revisited and reframed to continue research into development of Russian law without dismissing its potential to improve. 